\title{
Hearing Loss and Physical Functioning Among Adults with Heart Failure: Data from NHANES [Corrigendum]
}

Cosiano MF, Jannat-Khah D, Lin FR, Goyal P, McKee M, Sterling MR. Clin Interv Aging. 2020;15: 635-643.

Page 635, Abstract, Methods, the text "Multiple imputation was used to examine the association" should read "Negative binomial regression was used to examine the association between HL and physical functioning".

Page 637, Methods, Statistical Analysis section, third sentence, the text "The association between hearing loss severity and the physical functioning outcomes was determined using multiple imputation to adjust for demographic and other clinical covariates" should read "The association between hearing loss severity and the physical functioning outcomes was determined using negative binomial regression to adjust for demographic and other clinical covariates".

The authors apologize for these errors.

\section{Publish your work in this journal}

Clinical Interventions in Aging is an international, peer-reviewed journal focusing on evidence-based reports on the value or lack thereof of treatments intended to prevent or delay the onset of maladaptive correlates of aging in human beings. This journal is indexed on PubMed Central, MedLine, CAS, Scopus and the Elsevier
Bibliographic databases. The manuscript management system is completely online and includes a very quick and fair peer-review system, which is all easy to use. Visit http://www.dovepress.com/ testimonials.php to read real quotes from published authors. 